
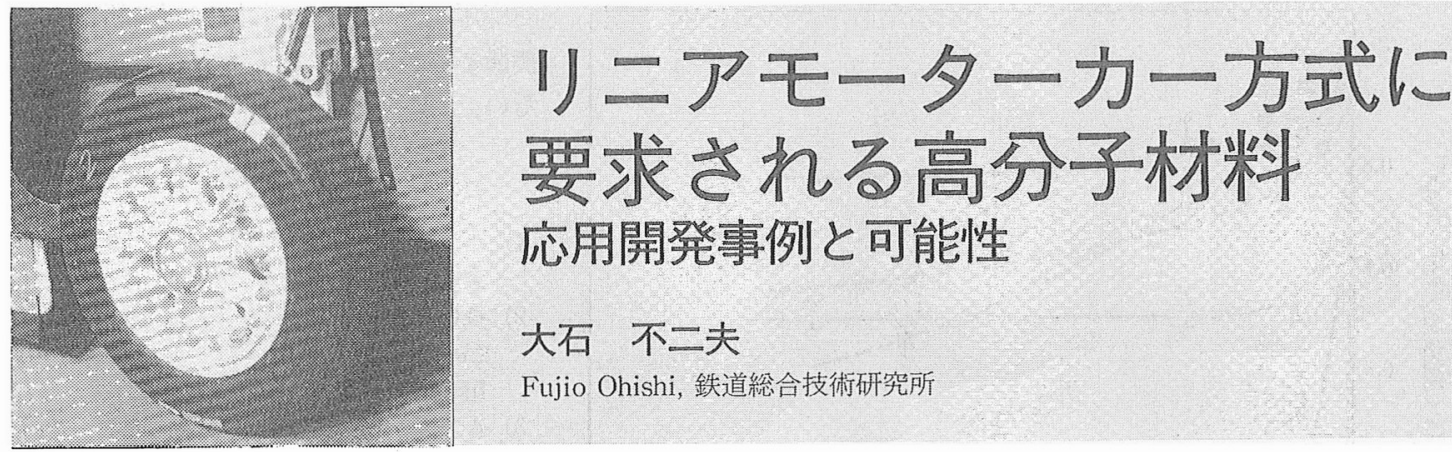

大石 不二夫

Fujio Ohishi，鉄道総合技術研究所

昨年 8 月, 運輸省は “リニアモーターカー・マグレ ブ”の実用化のため, 約 $50 \mathrm{~km}$ 延長の実験線の建設 を決定した，当研究所がおよそ四分の一世紀にわたり 続けてきた研究開発が，いよいよナショナルプロジェ クトとして実現へ向けて大きく前進することとなっ た、オリジナリティに乏しいと言われてきたわが国の 技術界にあって，しかも超電導フィーバーが定着化し つつある今日，この画期的な新技術の開発は transportation の分野だけでなく，土木・電気・電子・機械・ 制御・材料ほかほとんどの技術分野に関連し，テクノ ロジージャンプの好機でもある.

このシステムは昭和 35 年頃, 当時の鉄研の宇佐美 吉雄主任研究員の自発研究に始まり, 筆者らは 42 年 頃から参画し, 新幹線や在来線の研究開発とともに, 今日まで当研を中心に研究開発されてきたものであ る。本展望では，リニアモーターカー方式に関して筆 者らが行った約十件の研究開発(1) 3) の中から代表例を 紹介しながら，高分子材料へのニーズを提示してみた w.

\section{1. リニアモーターカー方式の原理と特徵}

リニアモーターカー方式（ここでは LM 式と略す） の原理は，これまでのモーター（ロータリー方式）を 切り開いて直線方向に拡げ，回転子を車上側に，固定 子を地上側に置き， $\mathrm{N}$ 極と $\mathrm{S}$ 極との吸引・反発作用 の電磁力を利用して, 推進・案内・浮上をさせるもの である.

これまでの鉄車輪一鉄レール間の摩擦力による推 進・案内・非浮上方式の鉄道と比べると，高速化の限 界が高く, 非接触であるため, 振動・騒音が低く, 材 料の摩耗がないなど画期的な特徵を有している.

LM 式のリニアモーターは誘導式と同期式とに大別

\section{写真=マグレブ宮崎実験車用支持タイヤ}

Polymeric Materials for Linearmotor Car Systems Developments and Applications
され, さらに常電導方式と超電導方式とに分かれる. 現在世界で開発が進められている LM 式のうち, 超電導磁気浮上リニアモーターカー方式（マグレブと 略記）は時速 $500 \mathrm{~km} \cdot \mathrm{h}^{-1}$ で東京〜大阪間 1 時間を目 指して鉄道総研で研究開発が続けられ, JR 方式とも 呼ばれている。一方 ALPS (Automated Linearmotor Pneumatictire System) は, 時速 $200 \mathrm{~km} \cdot \mathrm{h}^{-1}$ 程度で大都市圈内用や空港アクセス用を目指して，鉄 道総研で要素技術の研究とシステム開発が行われたも のである.ここでは, これら 2 方式の開発の一環とし て進めた研究開発事例を紹介し, 材料へのニーズを展 望してみる。なお,リニアモーターカーの概要につい ては，文献4),5)が参考となる。

\section{2. マグレブ超電導コイル用断熱荷重支持材の開発}

超電導コイル（車上極低温槽内）に生じた電磁力 （推進・案内・浮上）を車体へ伝える必要があるが，熱 は伝えたくない，そこで液体へリウム $(4.2 \mathrm{~K})$ と車 体の間を断熱しながら，極低温においても強度・剛性 に卓越した部材が不可欠となってくる.

そこで, 当所の浮上式鉄道研究室中島洋氏と共同で 神戸製鋼所 (株)浅田基礎研究所などの協力により開発 を進めた。当時入手し得る内外の ACM（先進複合材 料) の中から, 十数種の試料を選定し, 極低温から常 温までの熱伝導率と強度特性を調べた。ボロン・アラ ミド・カーボン・ガラス繊維とポリエステル・エポキ

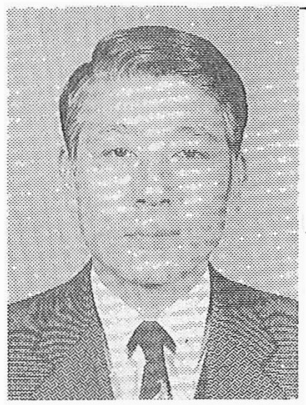

大石不二夫 (財) 鉄道総合技術 研究所 (185 国分寺市光町 2-8 -38）主幹研究員, 工博 1963 年都立大工学部工業化学 科卒. 1963 年日本国有鉄道入 社，1964 年鉄道技研へ配属. 有機化学ユニットリーダーを経 て現在, 主幹研究員 (理事長直 属)。高分子材料の耐久性の研 究, 高分子材料の鉄道への応用 開発を専攻。 


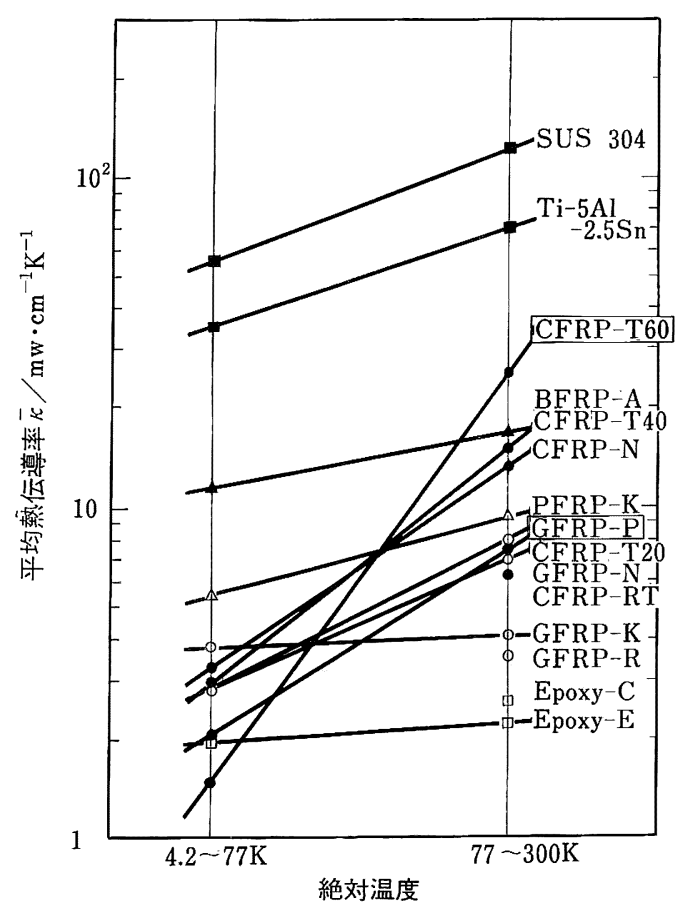

図 1 低温用断熱支持材料の平均熱伝導率

シ樹脂・ポリイミドなどとの組み合わせについて得ら れたデー夕から, 平均熱伝導率 $\bar{\varkappa}$ を図 1 に, 引張強 度 $\sigma$ を図 2 に示す。

図 1 に示すように, CFRP（カーボン繊維一エポキ シ樹脂，一方向圧縮成形品）は常温側では熱を伝えや すいが極低温側では熱伝導率が極めて小さいことが見 い出された。ことに CFRP-T60（カーボン繊維 60\%) は, 極低温での熱伝導率が最小で, しかも引張強さが $100 \mathrm{~kg} \cdot \mathrm{mm}^{-2}$ を越えるほど大きく， $/ \bar{\varkappa}$ の值が 71.4 （77〜 $4.2 \mathrm{~K}$ 間）と最大である.一方，常温側では GFRP-P（ガラス繊維 75\%-ポリエステル・エポキシ 混成樹脂, 一方向連続引抜成形品）が, 熱伝導率が比 較的小さく, 引張強さが $84 \mathrm{~kg} \cdot \mathrm{mm}^{-2}$ 以上と大きく, $\sigma / \overline{\mathcal{\varkappa}}$ は 10.5 (77〜 $300 \mathrm{~K}$ 間) とこの温度域では最大 である6.

そこで，真空層と幅射熱反射のためのアルミニウム 管も含めた複層管構造として, 極低温の液体へリウム 側の外層を CFRP 製管, 常温の車体枠側の内層を GFRP 製管とするハイブリッド構造とする提案を行 った．この方式はステンレス鋼に代わって, 宮崎実験 線の実験車 MLU-001, -002 などに適用されている.

\section{ACM の車体軽量化への応用}

車両の軽量化は，省エネルギー化のみならず，高架

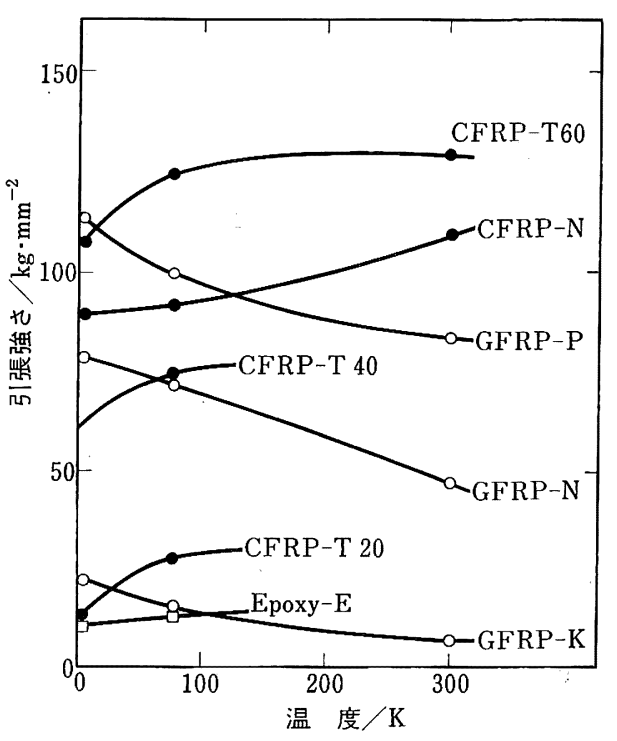

図 2 FRP の引張強さの温度依存性

橋など構造物の簡易化に有効でしかも振動・騒音の低 減にも効果がある。とりわけりニアモーターカーのマ グレブは浮上するため必須であるが，ALPS も支持 用ゴムタイヤの使用限度を示す限界 WS 值が輪重に 比例することから，とくに重視される。

そのため当所において車両の軽量化に関する研究開 発が種々なされてきているが，ここでは筆者らが参画 した ALPS のシステム開発の一環として進めた，車 両構体への ACM の応用8) を紹介する。 なおこの研究 は ALPS 車両に限らず，マグレブやスーパー新幹線 車両などへも応用できるものである。

ALPS はゴムタイヤの荷重負担を $2 \mathrm{t} /$ 輪以下にする

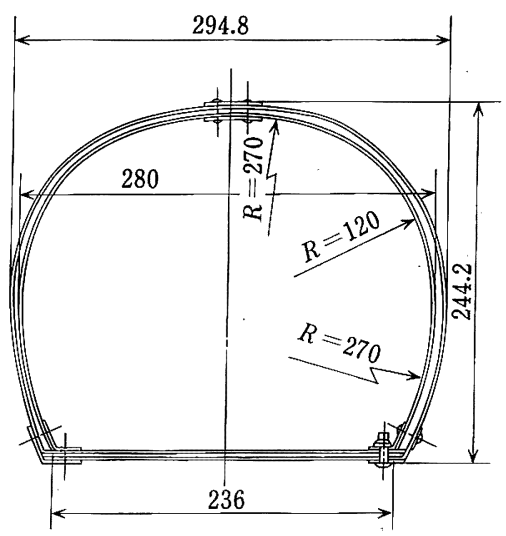

長さ： $2000 \mathrm{~mm}$

図 3 ALPS 用 1/12 サイズ車両構体模型 
表 1 同一曲げ剛性における比較

\begin{tabular}{|c|c|c|c|c|c|}
\hline 種 別 & 材 質 & $\begin{array}{l}\text { パネル厚 } \\
\text { さの比 }\end{array}$ & 重量比 & 破壤荷 & $\begin{array}{l}\text { コス } \\
\text { 卜比 }\end{array}$ \\
\hline 普通鋼版 & SS 41 & 1 & 1 & 1 & 1 \\
\hline アルミ板 & A 5083 & 1.5 & $1 / 2$ & 1.1 & 2.5 \\
\hline $\begin{array}{l}\text { アルミ表面 } \\
\text { アルミハム }\end{array}$ & $\begin{array}{c}\text { A 5052 } \\
1 / 4-3003-002\end{array}$ & 2.5 & $1 / 10$ & 4.5 & 6 \\
\hline $\begin{array}{c}\mathrm{CFRP} \text { 表面 } \\
\text { ハニメッ } \\
\text { ハニカム }\end{array}$ & $\begin{array}{c}\mathrm{P} 201 \\
\mathrm{HRH}-10^{-}-3 / 16-6.0\end{array}$ & 2 & $1 / 20$ & 1.7 & 20 \\
\hline $\begin{array}{l}\text { GFRP 表自 } \\
\text { アルミハニカム }\end{array}$ & $\begin{array}{c}\text { SPG-100 } \\
\text { A } 1 / 8-5052-002\end{array}$ & 3.5 & $1 / 8$ & 7 & 10 \\
\hline
\end{tabular}

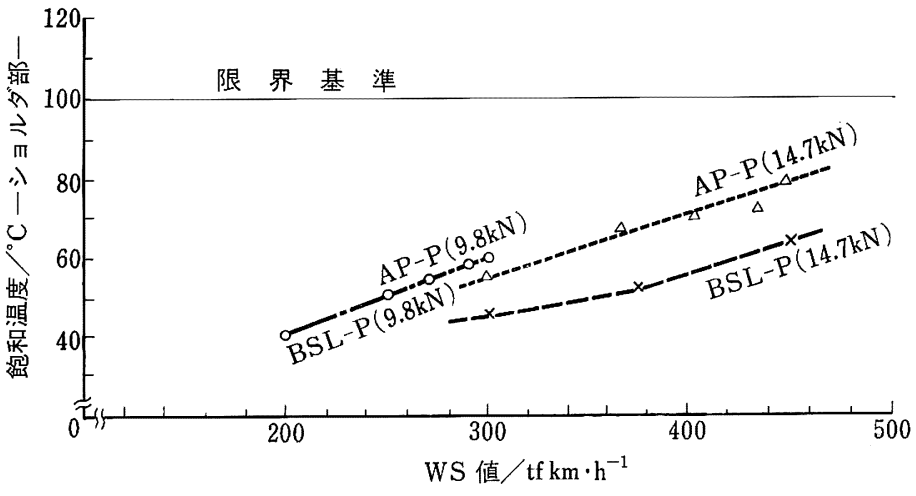

図 4 AP-P, BSL-P タイヤの限界特性
これに住友ゴム工業(株)と横浜ゴム (株)が加わり, 共同で試作, 評価を進 め, 完成することができた8).

ゴムタイヤの使用限度を示す限界 $\mathrm{PV}$ 值（常用最高の輪重 $\times$ 時速）は, 既存の夕イヤでは $300 \mathrm{tf} \mathrm{km} \cdot \mathrm{h}^{-1}$ 以下 であるが, 試作評価を重ねた結果, 図 4 に示すように，400を越え500に近 づくタイヤを作ることができた．これ らはいずれもトレッドゴムを薄くして ゴムの粘弾性発熱を抑制し, トレッド パターンを除いたプレインタイヤであ る. 宮崎実験線のマグレブ用として は, 輪重約 $3 \mathrm{t}-400 \mathrm{~km} \cdot \mathrm{h}^{-1}$ で短時間 走行が可能であり, $500 \mathrm{~km} \cdot \mathrm{h}^{-1}$ から の緊急着地 3 回まで可能な支持, 案内 タイヤを完成し, 実験線で使用されて きた7).ただ耐摩耗性の向上など実用 化に向けての研究は今日も続いてい る. ALPS 用には (アラミドコード の適用など）約十種の支持，案内用夕 イヤを試作評価し, 支持用には AP-P タイヤ, 案内用 (小形) には, GK-P タイヤ(アラミドコード製カーカス) を提案することができた8).

\section{5. 雪水固着防止コーティングの応用開発}

新幹線の降雪による遅れをはじめとして, 鉄道の雪 氷害は深刻である。リニアモーターカーの降雪や積雪 による被害を防ぐ対策が必要である理由は，たとえ約 $10 \mathrm{~cm}$ 浮上しても，ガイドウェイの底面や側面の着雪 が水結して固着すると除雪装置（別途開発中）の移動 が困難となる。 また低速・緊急用の支持, 案内夕イヤ の昇降装置（車体側）に降雪が侵入して承結すると作 動に支障が出るおそれがある。これらマグレブ関係だ けでなく，広く鉄道の雪氷害を防ぐため，新しい機能 性高分子を応用した雪水固着防止コーティングの開発 を, 関西ペイント(株)技術研究所の村瀬平八氏らと共 同で進めてきた ${ }^{9)}$.

その結果生み出された新コーティング材の例を示 す.まず着雪は氷結する場合が圧倒的に多いことに着 目し, 着水力を極端に下げた試作(6)が生れた。これは Li イオンをシリコーンポリマーに結合させて, 水分 子の $\mathrm{H}-\mathrm{O}-\mathrm{H}$ の結合角が, 水となるとき $104^{\circ}$ から $109^{\circ}$ 八拡大するのを抑制して, 脆弱な水を界面に生 成させる機能をもたせたものである．この着氷力は着 水しにくいとされている四フッ化エチレン樹脂や海外 


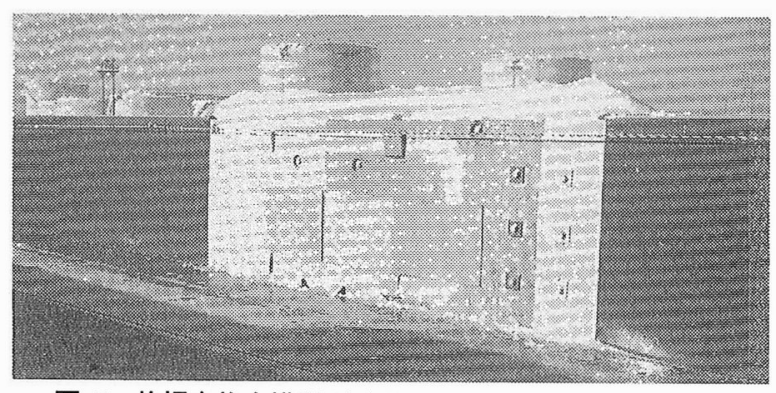

図 5 札幌実物大模型ガイドウェイにおける除雪性試験

の類似コーティング材と比べ極めて小さい值となって いる。 また最近の試作(20はフッ素ーシリコーンポリマ ーであり, 分子設計の結果, 表面の水滴の接触角が $155^{\circ}$ と極めて大きく, 着氷力や着雪力が最も小さい. この塗装板は札幌における自然降雪の中に立て掛けら れてもほとんど着雪せず，当所の塩沢雪害実験所の天 然雪を用いる風洞実験においても，乾き雪はほとんど 付着せず，水を含ませた濡れ雪では着雪するが，容易 に除雪しやすいことが確認された。また着雪装置 でも最小の除雪力を示した. そこで, 図 5 に示すよう に, マグレブガイドウェイ実物模型を用いて，除雪の 容易さを実地で調べている

\section{6. 弚の他の応用開発例}

以上の 4 例のほかに LM 式に関して，筆者らが行 った応用開発課題を次に列挙し，リニアモーターカー 方式の高分子材料への要求を示す.

৩「リニアインダクションモーター (LIM) 方式のポ リウレタン製ガイドローラーの開発」：リニアモータ 一参画の最初のテーマであり, 注型ウレタン（ゴム硬 度 JIS-A98) で試み, 輪重 $1 \mathrm{t}-500 \mathrm{~km} / \mathrm{h}$ 条件のソリ ッドタイヤを試作し, 高速高荷重特性を調べた。

৩「LIM ガイド用高分子軌条の開発」：LIM 用や ALPS の案内タイヤ用に, 軽合金車輪と走行路面側 への高硬度ポリウレタンライニングとの組み合わせを 試み約 $20 \mathrm{~m}$ の鉄桁上儿試験施工し，十年以上屋外暴 露して変状を調べ, 可能性をつかんだ?.

৩「マグレブの支持タイヤ走行路面材の検討」：宮崎実 験線の建設時に，樹脂舗装材を提案したがコスト上採 用されなかった，その後，ゴムタイヤの摩耗低減のた め走行路面材が再び検討されている.

৩「マグレブのガイドウェイ用プラスチック筋材の開 発」: 宮崎実験線建設時に, 磁気の影響を除くためコ ンクリートの鉄筋の代りに, FRP の連続引抜筋（四 凸を長手方向に形成）を開発し，提案したがコス卜 上, 非磁性鋼が採用された. その後当所の涌井一主任
研究員らにより FRP 製筋材・緊張材の開発が進めら れている.

৩「グレブ地上コイルのコンクリート内埋込材の開 発」: 推進, 案内兼用と浮上用のコイルをコンクリー トスラブ内埋込式とするために，2 次絶縁を兼ねた工 ポキシ樹脂モルタル等を日立化成工業(株)の協力で開 発した. 最近は 1 次絶緑も兼ねる埋込材の研究も進め られている。

৩「マグレブ地上コイルのケーブルソケットの簡易 化」: 推進, 案内兼用の地上コイルそれぞれへ電気を 供給するための端末ソケットは, $5.8 \mathrm{kV}-900 \mathrm{~A}$ と高 圧高電流を絶縁するために高価となる。これを簡易 化，コストダウンさせるためにシリコーンゴム等のシ ュリンクチューブを提案した。

\section{LM 式の実用化に向けての高分子材料へのニーズ}

以上，LM 式に関連して筆者らが進めた応用開発を 十例提示したように, ニーズが求める開発の多くは既 に着手されている。これらの課題をさらにブレイクス ルーしたり, 深度化をはかることが求められている。 それらも含めて, マグレブや ALPS のニーズの強い ものを列挙すると，次のようになろう。

“超電導コイル用断熱荷重支持材” “ヘリウム液化冷 凍器用断熱接着剤, 弁” “車上, 地上コイルの絶縁材” “地上コイルのコンクリート埋込絶緑材” “超軽量構 体, 車体枠” “車両内装材” “車両用防振, 防音材” “空気抵抗低減材” “推進, 案内コイルの簡易ソケッ 卜”“耐摩耗性ゴムタイヤ” “夕イヤ走行路面材” “雪 承害防止材” “案内, 表示等旅客サービス用材料” 等.

扔わりに，マグレブ等新しい鉄道システムのクリエ イションは, 新しい材料システムの創造により実現す ることを強調しながら結びたい.

\section{引用文献}

1) F. Ohishi : Applications of Advanced Composites to Advanced Railway Systems, Proc. MRS'88 (1988)

2) F. Ohishi: Applications of Polymeric Materials to Railways, Proc. Rubber Con'88 (1988)

3) F. Ohishi : Developments and Applications of Polymeric Materials to Railways, Proc. 2nd International Plastics Conference (1989)

4）松岡孝一: RRR, 45, (4) 12 (1988)

5）鉄道総研, 浮上式鉄道開発推進本部：リニアモーター カー・マグレブ, 清文社 (1988)

6) 中島 洋, 大石不二夫, 川平剛雄他: 第 15 回低温工学 研究発表会, 前刷 (1975)

7）U 研究グループ: 鉄研報告 No.7 (1972)

8）ALPS-B102 研究班: 鉄研報告, No. 1200 (1981)

9）大石不二夫, 村瀬平八, ほか: 雪水, 49, 1 (1987) 